\title{
Renewable Insulation Materials Constructed from Colombian Materials According to the Principles of Sustainable Development: a Review
}

\author{
Desarrollo y Pruebas de Materiales Colombianos de Aislamiento Acústico de Acuerdo con los \\ Principios de Desarrollo Sostenible: una Revisión
}

\author{
Marcelo Herrera Martínez ${ }^{1,2 *}$, Darío Alfonso Páez Soto² \\ ${ }^{I}$ School of Engineering and Natural Sciences, Faculty of Mechanical and Informatics Engineering, University of Iceland, Reykjavik, \\ Iceland \\ ${ }^{2}$ GRIAP-Grupo de Investigación en Acústica Aplicada, Ingeniería de Sonido, Universidad de San Buenaventura, Bogotá, Colombia
}

\begin{abstract}
The growing demand for building materials requires the development of environmentally friendly materials with excellent use properties and reasonable prices. One of the major objectives of materials research in the construction industry is the use of renewable resources from waste materials from industries for the development of new building materials. The current trend of thermal insulation of buildings has resulted in the development of materials for insulation based on renewable resources of agriculture. This article describes the research and development of insulation materials based on natural fibres of agricultural origin; in particular, guadua fibres, sugar cane, hemp, flax and jute.
\end{abstract}

Keywords: Non-conventional materials, Acoustic and thermal insulation, Sustainable Development.

\section{Resumen}

La creciente demanda de materiales de construcción requiere del desarrollo de materiales amigables con el medio ambiente, con propiedades de uso excelentes y con precios razonables. Uno de los principales objetivos de la investigación de materiales en la industria de la construcción es el uso de recursos renovables de materiales generados por desecho de industrias, para el desarrollo de nuevos materiales de construcción. La tendencia actual de aislamiento térmico de construcciones ha resultado en el desarrollo de materiales para aislamiento basados en recursos renovables de la agricultura. Este artículo describe la investigación y el desarrollo de materiales de aislamiento basados en fibras naturales de origen agrícola; en particular fibras de guadua, caña de azúcar, cáñamo, lino y yute.

Palabras clave: Materiales no convencionales, Aislamiento térmico y acústico, Desarrollo Sostenible.

\section{Introduction}

Nowadays, the development of new perspectives in the construction of materials without having negative effects on the environment, and being at the same time economic with optimal properties has been object of research [1].

\footnotetext{
*Corresponding Author.
}

E-mail:marcelo@hi.is
In this manner, the principles of Sustainable Development may be fulfilled. Some applications of sound engineering have contributed relevantly to the matter, mainly in the development of acoustic materials that may be harmless to the environment [2] [3].

How to cite: Herrera, M., Páez, D. A., Renewable Insulation Materials Constructed from Colombian Materials According to the Principles of Sustainable Development: a Review, TECCIENCIA, Vol. 13 No. 24, 27-42, 2018

DOI: http://dx.doi.org/10.18180/tecciencia.2017.24.4 


\section{TECCIENCIA}

In construction, for instance, it is desired to achieve good results in acoustic insulation as well as in thermal insulation [4]. The correct performance of these materials is a keypoint on the state of the environment [5]. This is the main reason for scientific research in finding environmentally friendly insulation and conditioning materials. The trend in today's world is the appropriate use of natural resources, recycled materials and waste fibers.

Since ancient times, thermal insulation systems have been constructed from natural resources such as cane, straw, hay, flax, hemp and lichen. With the development of civilization and the increasing requirements for quality in construction, these materials were replaced with synthetic ones (plasters, polystyrene, polyurethane, polyvinyl chloride and polyethylene). As well, inorganic materials were also begun to be used, such as, mineral wool [6]. The production of the current insulation materials is complicated, both from energy, resource and financial perspectives [7]. Hence, the finding of alternative resources is then prioritized. From the environmental perspective it is advisable to use renewable resources -local sources- with production that requires low energy. All this is aligned with the WHO and UNO directives [8] [9] [10] [11]. One possibility is the use of resources from agriculture. Another variant is the use of waste materials, i.e. those materials that can be recycled. With an appropriate use of these properties you can build modern constructions that have a thermal comfort and pleasant humidity conditions.

The use of thermal and acoustic insulation materials and the correct design of buildings from the point of view of energy saving, are a key point in the reduction of energy requirements. This also minimizes greenhouse gas emissions, which has a direct effect on the environment. Currently, this theme is significant due to global warming.

The main objective of this article is to inquire about new cost-effective insulation materials and at the same time to be able to access natural resources available.

\section{Background}

We may classify insulation materials according to:

a) The function of insulation materials

b) The source of insulation materials

\subsection{Insulation against water and humidity}

In this group are the insulation materials that protect the object against water. This group can then be classified into waterproofing (insulation against water, and moisture), and insulation against wind moisture.

\subsection{Materials of thermal insulation}

These materials stop the transmission of heat from the place where there is more temperature to the places where there is less temperature. Its main role is in minimizing the thermal losses of the construction.

\subsection{Acoustic insulation materials}

Basically, protection against noise. The general functions of this group of insulation materials is to limit and correct the propagation of mechanical and sound waves in civil constructions. These materials solve the problem of noise in civil constructions and this in the subject of structural attenuation and attenuation of the air, where it tries to limit the propagation of the noise in the later constructions in the sound absorption, where it is tried to direct and optimize the Sound parameters in the listening region and intelligibility.

\subsection{Special insulation materials}

Insulation against radon, chemical insulation, insulation against electromagnetic waves and ionic radiation. [12] [13] [14] [15]. According to their origin, we have: a) synthetic insulation materials (classic), and b) natural insulation materials. During the selection of insulation materials, which may be suitable for construction (synthetic, natural), it is necessary to take into account the thermal technical properties of the material as well as the impact on the environment. With the increasing number of inhabitants, $\mathrm{CO} 2$ emissions also increase. For material evaluation it is also necessary to observe its ecological footprint.

In order to solve this problem, it is necessary to define the energy rate and the influence of the products on the environment. Three aspects are defined: a) The amount of energy involved (PEI-Primary Energy Input in the given material in $\mathrm{MJ} / \mathrm{kg}$ ). b) $\mathrm{CO} 2$ emission (GWP-Global Warming Potential) in kg. c) Emission of SO2 (APAcidification Potential). As an element equalized for AP is also $\mathrm{SO} 2$, as well as other oxides. AP gives us the wider information of nature by the effect of industrial production [16] [17].

The synthetic insulation materials originate with the synthesis of inorganic and organic components [18] [19] [20]. These are for example polystyrene (EPS, XPS), mineral wool, polyurethane and others. This set of synthetic insulation is classified according to its chemical behavior in: a) Materials of mineral insulation (inorganic). b) Organic insulation materials. For the production of synthetic insulation materials, it is necessary to have available not only sufficient sources, but also a large amount of energy for the production process. Mineral inorganic insulation comes from technological processes such as basalt. 


\section{TECCIENCIA}

The result of this process is an insulation material in the form of fibers. The input material in organic insulation materials is petroleum and its derivatives. Here the question is the future value of this non-renewable source.

\section{Natural insulation materials based on renewable sources}

Current ideas are focused on the use of systems that can be permanently preserved. On the other hand, there are doubts about the exploitation of resources and energy sources, from the point of view of environmental contamination. Another key point is the recycling capacity of these materials. These trends are also projected in the field of construction. At present, therefore, great attention is paid to organic-based materials, i.e. natural resources, which if they meet this condition of timeless preservation.

In Europe, for example, there is an increasing tendency to use thermal insulation materials that are made from organic sources from agriculture, but also from the recycling of waste products from other branches of production [21]. In France, Germany and Austria, these materials are directly related to the construction of low energy house, but at the same time quality, ecological and economic [22] [23] [24]. The reasons for returning to insulation materials and alternative resource materials in construction are: a) They are renewable materials. b) Their properties are close to the needs of the human organism: from the point of view of the internal humidity of the microclimate. c) Reduction of the energy requirements for its production. d) A simpler recycling of these products is possible after the end of a natural life. e) More economical. f) In the near future, the construction will be done with passive and lower energy elements [25] [26] [27].

On the other hand, there is research on the influence of constructions on the health of people. For example: a) IAP (Indoor Air Pollution)- Negative influence of contaminants from the physical, chemical and biological point of view. b) SBS (Sick Building Syndrome) - Negative influence of the human in the buildings, without needing a clear motive. c) BRI (Building Related Illness), diseases, in which it is demonstrated that reason is the building per se.

As it is possible to observe in table 1, the emissions of $\mathrm{CO} 2$, and $\mathrm{SO} 2$ in the natural materials are smaller in comparison with the materials commonly used in construction. However, there are also negative factors in natural materials, such as greater sensitivity to moisture, and worse reaction to fire compared to current insulation systems. If we have a time of excessive humidity, this can lead, for example, to biological corrosion, i.e. to degradation caused by bacteria or fungi.
Table 1 Selected classic and natural insulation materials and their values of energetic ratios PEI and their degree of influence on the quality of the environment (GWP and AP parameters) [28].

\begin{tabular}{|l|l|l|l|l|}
\hline $\begin{array}{l}\text { Insulation } \\
\text { material }\end{array}$ & $\begin{array}{l}\text { Density } \\
{[\mathbf{k g} /} \\
\left.\boldsymbol{m}^{3}\right]\end{array}$ & $\begin{array}{l}\text { PEI } \\
{[\mathbf{M J} / \mathbf{k g}]}\end{array}$ & $\begin{array}{l}\text { GWP } \\
{\left[\mathbf{k g} \mathbf{C O}_{2} \text { eqv }\right.} \\
/ \mathbf{k g}]\end{array}$ & $\begin{array}{l}\text { AP } \\
{\left[\mathbf{k g ~ S O _ { 2 }} \text { eqv }\right.} \\
/ \mathbf{k g}]\end{array}$ \\
\hline $\begin{array}{l}\text { Hemp mats } \\
\text { without PE } \\
\text { fibres }\end{array}$ & 30 & 27,100 & $-0,377$ & 0,00437 \\
\hline $\begin{array}{l}\text { Hemp mats } \\
\text { with PE } \\
\text { fibres }\end{array}$ & 30 & 31,100 & $-0,133$ & 0,00539 \\
\hline Flax mats & 30 & 34,00 & 0,121 & 0,00772 \\
\hline $\begin{array}{l}\text { Flax mats } \\
\text { with PE } \\
\text { fibres }\end{array}$ & 30 & 38,000 & 0,364 & 0,00874 \\
\hline Sheep wool & 30 & 14,700 & 0,045 & 0,00266 \\
\hline Cork & 120 & 7,100 & $-1,230$ & 0,00274 \\
\hline Glass wool & 25 & 49,800 & 2,260 & 0,01600 \\
\hline $\begin{array}{l}\text { Celulosa } \\
\text { (free) }\end{array}$ & 35 & 7,030 & $-0,907$ & 0,00341 \\
\hline $\begin{array}{l}\text { Mineral } \\
\text { wool }\end{array}$ & 33 & 23,30 & 1,640 & 0,01050 \\
\hline $\begin{array}{l}\text { Mineral } \\
\text { foam } \\
\text { (Multipor) }\end{array}$ & 115 & 4,770 & 0,474 & 0,00111 \\
\hline EPS F & 18 & 98,500 & 3,350 & 0,02160 \\
\hline $\begin{array}{l}\text { XPS } \\
\text { foamed } \\
\text { with CO2 }\end{array}$ & 38 & 102,000 & 3,440 & 0,02110 \\
\hline
\end{tabular}

Table 2 World consumption and physical properties of relevant fibres [29].

\begin{tabular}{|l|l|l|l|l|}
\hline $\begin{array}{c}\text { Bast } \\
\text { fibers }\end{array}$ & $\begin{array}{c}\text { World } \\
\text { consumption } \\
\text { [thousands of } \\
\text { tons] }\end{array}$ & $\begin{array}{c}\text { Average } \\
\text { length } \\
{[\mathbf{m m}]}\end{array}$ & $\begin{array}{c}\text { Average } \\
\text { softness } \\
{[\boldsymbol{\mu m}]}\end{array}$ & $\begin{array}{c}\text { Relative } \\
\text { strength } \\
{[\mathbf{m N / t e x}]}\end{array}$ \\
\hline Jute & 2850 & $2-4$ & $15-20$ & $53-196$ \\
\hline Flax & 850 & $17-20$ & $12-17$ & $440-530$ \\
\hline Hemp & 214 & $10-14$ & $14-17$ & $290-690$ \\
\hline Ramie & 170 & $50-65$ & $30-50$ & $500-900$ \\
\hline Cotton & 26000 & $19-38$ & $10-17$ & $245-370$ \\
\hline
\end{tabular}

The reaction to fire in natural materials is possible to improve it with elements that delay the initialization of fire. Within the materials constituting fibers of natural origin are, for example, sheep's wool.

The natural fibers that can be obtained from different parts of the plant are distributed in the following groups:

- Linen fibers (hemp, flax, jute),

- Cotton fibers,

- Fibers from leaves of plants (abaca),

- Fruit of plants (coconuts).

Table 2 shows how flax fibers are used worldwide and their physical properties. 


\section{TECCIENCIA}

Table 3 Selected physical properties in natural construction materials used in buildings.

\begin{tabular}{|c|c|c|c|c|}
\hline Material & $\begin{array}{l}\text { Coefficient } \\
\text { of thermal } \\
\text { conductivity } \\
\text { in dry state } \\
{\left[W \cdot m^{-1} \cdot K^{-1}\right]}\end{array}$ & \begin{tabular}{l|} 
Mass \\
Volume in \\
dry state \\
$\rho_{v, d_{n}\left[\mathrm{~kg}_{\mathrm{m}} \mathrm{m}^{-3}\right]}$
\end{tabular} & $\begin{array}{l}\text { Average } \\
\text { mass in dry } \\
\text { state } \\
\quad c_{d n} \\
{\left[\mathrm{~J} \cdot \mathrm{kg}^{-1} \cdot \mathrm{K}^{-1} \text { ] }\right.}\end{array}$ & $\begin{array}{l}\text { Dry/Wet } \\
\text { factor of } \\
\text { diffuse } \\
\text { resistanc } \\
\text { e } \mu_{n, d} / \\
\mu_{n, w}[-]\end{array}$ \\
\hline Flax & 0,040 & $20-40$ & 1600 & $1 / 2$ \\
\hline $\begin{array}{l}\text { Technical } \\
\text { hemp }\end{array}$ & 0,040 & $20-25$ & 1600 & $1 / 2$ \\
\hline $\begin{array}{l}\text { Wood- } \\
\text { fiber } \\
\text { plates: } \\
\text { Rigid } \\
\text { Flexible }\end{array}$ & $\begin{array}{l}0,070 \\
0,040\end{array}$ & $\begin{array}{l}160-250 \\
40-60\end{array}$ & $\begin{array}{l}2000 \\
2000\end{array}$ & $\begin{array}{l}5 / 10 \\
1 / 2\end{array}$ \\
\hline $\begin{array}{l}\text { Coconut } \\
\text { fiber: } \\
\text {-role } \\
\text {-matting }\end{array}$ & $\begin{array}{l}0,050 \\
0,045\end{array}$ & $\begin{array}{l}75-80 \\
120-135\end{array}$ & $\begin{array}{l}1650 \\
1650\end{array}$ & $\begin{array}{l}1 / 2 \\
5 / 10\end{array}$ \\
\hline $\begin{array}{l}\text { Cork: } \\
\text { - } \\
\text { granulate } \\
\text { d } \\
\text {-plates }\end{array}$ & $\begin{array}{l}0,050 \\
0,058\end{array}$ & $\begin{array}{l}55-60 \\
80-500\end{array}$ & $\begin{array}{l}1560 \\
1560\end{array}$ & $\begin{array}{l}5 / 10 \\
5 / 10\end{array}$ \\
\hline $\begin{array}{l}\text { Granulate } \\
\text { d }\end{array}$ & 0,050 & $100-120$ & 1900 & $2 / 3$ \\
\hline $\begin{array}{l}\text { Sheep } \\
\text { wool }\end{array}$ & 0,040 & $20-25$ & 1700 & $1 / 2$ \\
\hline Cane & 0,050 & 190-225 & 1870 & $1 / 2$ \\
\hline Sea grass & 0,045 & $70-80$ & 2000 & $1 / 2$ \\
\hline $\begin{array}{l}\text { Strawbale } \\
\text { s }\end{array}$ & 0,066 & $90-110$ & 1800 & $2 / 4$ \\
\hline Hay & 0,040 & $30-65$ & 2196 & $1 / 2$ \\
\hline
\end{tabular}

In Table 3, the characteristic physical properties for natural insulation materials are recorded. The most significant properties of thermal insulation materials are the thermal conductivity coefficient lambda (W/ mK). Based on the characteristics of these values it is possible to verify that the coefficient of thermal conductivity in synthetic and natural materials differs. Another parameter is the heat capacity $\mathrm{C}(\mathrm{J}$ $/ \mathrm{kg} \mathrm{K})$. The tabulated values of average thermal capacity in the dry state are in natural materials higher than in inorganic materials, such as mineral wool. The normalized range of volume mass in dry state $\rho_{d, n}$ is influenced by technologic processing of natural sources. The diffuse resistance factor (dry, moisture) of natural materials is close to synthetic insulation materials of the glassy type, or mineral wool.

\section{Natural resources}

\subsection{Cannabis (Cannabis sativa L.)}

\subsubsection{History and topicality of hemp grown}

The hemp is an ancient plant, whose beginnings go back to Asia Media, China, and India in the time of the 3 century BC [30].
In Europe, hemp plantations began in the 7th century BC. The area of hemp planting within the European Union, decreases vertiginously. Comparing the area of plantations from 2005 to 2010, within the European Union, we have the most dramatic decline in the years 2008 and 2009, where the area of hemp plantations obtained up to 10544 hectares in the EU countries [31].

\subsubsection{Hemp characteristics}

Hemp is characterized by being a plant of $80-350 \mathrm{~cm}$ high The plant creates a fusiform root that deepens in the earth about $30-40 \mathrm{~cm}$. The stem is straight, according to the type of hemp reaches lengths up to $4 \mathrm{~m}$, and widths of $3 \mathrm{~cm}$. At the base, the plant is spherical, in the center it has 6 faces, and at the top 4 faces. It is hollow, distributed in 7-15 internodes. The smaller the internodes, and their longer length, the fiber is of more quality.

From the chemical point of view, cannabis fibers consist of cellulose $(70.2-74.4 \%)$, hemicellulose $(17.9-22.4 \%)$, lignin $(3.5-5.7 \%)$, pectin \%), Waxes $(0.8 \%)$, water $(10.8 \%)$. The remaining $6.1 \%$ is composed of other components (resin, ash and protein). Due to its organic nature, hemp has a high absorption capacity (80-100\%), low density (80 kg / $\mathrm{m} 3$ ), and low mass (1500 kg / m3) [32] [33] [34] [35].

\subsubsection{Use of hemp products}

Hemp as an important source of natural fiber and organic matter has a variety of uses. It is a plant that can be used worldwide without generating waste. Hemp fibers, stems and seeds are very often used. Hemp fiber is used in the production of conventional textile materials (canvas, denim, decorative fabrics and upholstery, carpets), the production of special products and industrial products (ropes, ropes, threads, strings, bags of cloth, strings, tires), followed by fibers of lower value and short find application in the construction industry as part of building materials with good thermal and acoustic insulation properties (insulation mats, mineral fiber boards, enrichment of felt geotextile). It is also used as upholstery and sealing material. Fibers are a potential source of plant pulp for the production of gasoline, coal, methanol, gas and electricity [36] [37].

Straw, waste from the transformation of rods into fibers containing a substantial amount of cellulose, has a wide range of applications. It can be used in the paper industry (cigarette paper, filters, bank notes), followed by construction (Pazdera-hemp panels, construction partitions, etc.), in the automobile industry (a blend of hemp fibers and Shiv used as filler and insulation materials). It is also used in the form of pellets as an ecological fuel or as a bed for animals. Hemp seed have a broad spectrum of applications. 


\section{TECCIENCLA}
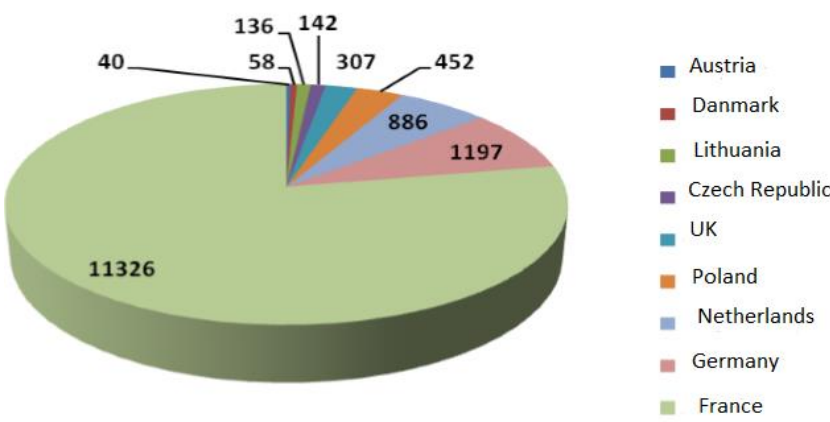

Figure 1 Graphic representation of sowing area of flax in EU countries in the years 2009/2010

We find them in food (canning), chemical industry (production of lacquers, varnishes, lubricating oils, soaps), cosmetics industry (skin creams, hair care products, etc.) [38] [39]. And veterinary (dermatological products), serve as well as food for birds and fish. The application is also flowers and plants to meet them can in the food and cosmetic industry. The whole plant can be used in the cultivation of biomass and the use for energy purposes to combustion [40].

\subsection{Linen}

\subsubsection{History}

Flax belongs to one of the oldest fibers, whose crops have been known since the time of Mesopotamia (6000 BC) [41]. Flax fibers have been built fibers, ropes, and nets. From this became the transport of linen to Egypt, where not only the cultivation became popular but also the processing. Proof of this are the linen fibers in which the mummies of the pharaohs were made. The cultivation spread to Persia, and later to the Mediterranean and India. The Romans together with the Slavs took the flax crops in Europe. The world production of long-fiber flax is concentrated in the lands of western Europe.

In recent times, there has been a decline in the cultivation of flax throughout the world. In Western countries like France, Belgium and the Netherlands, which constitute a quarter of the world production of this product. The main reason is the low prices of linen resources in the market.

\subsubsection{Characteristics of flax}

The linen family comprises about 200 types, of which the type Linum usitatissimum L. is the most renown [42]. According to the length of the vegetation time is divided into:

a) Linum angustifilium

b) Linum usitatissimum
According to the size of the seed, the flax is divided into:

a) Macrosperm

b) Microsperm

Flax has a longer, softer branched stem. The resource is stems that when processed are long fibers and short fibers, called towing. They are constructed from the fibers, bags, cigarette papers. Of the seeds is produced technical support (for production of color, lacquer, linoleas, imitation of leather), sometimes even can be used to feed animals [43].

The flax is shorter and thicker ramified inflorescence stems and a larger number of capsules. Flax seeds are used in the food industry, food industry and for technical purposes. Stems are a byproduct, fiber is thicker than fiber type and difficult to spindle. It can be processed in a trailer or for use in the paper industry. In a world we often encounter this type of flax.

Linen grows to a height of $150 \mathrm{~cm}$, the vegetation period is around 90 days. Flax stems are erect, densely leafy. The leaves are linear-lanceolate to linear and acute. The flowers are in inflorescences, capsules, egg-shaped blue or white light are round [44]. The stem forms a waxy cuticle or skin covering layer below which is also a part of the stem bast consisting of the primary cortex, cortical parenchyma layers of starch, fiber bundles and the tube member of Secondary phloem sieve bark [45]. Bast part of the stem is made up of 40 to $50 \%$ of its weight. Woody part of the stem, representing a substantial part of the stems, constitutes 50$60 \%$ of the total weight of the stem. The fiber content in the stem varies about 25 to $30 \%$ of the stem weight. The quality of the fiber is expressed in TEXech. TEX is a mass of $1 \mathrm{~km}$ of grams of fiber. The lower the TEX value is lower, the better quality. Flax is sensitive to water and therefore grown in areas with annual rainfall above $600 \mathrm{~mm}$.

The chemical nature of flax fiber consists of cellulose (71-75\%), followed by hemicellulose (18.6-20.6\%), lignin $(2.2 \%)$, pectin $(2.2 \%)$, waxes $(1.7 \%)$, and other components $(3.8 \%)$ and water $(10 \%)$. The color of the clothing is natural, from light blond to darker shades of green, brown and gray. Len has a natural sheen, stands out in great resistance and ability to absorb moisture. Flax fibers can take up to $30 \%$ water is not moist to the touch. Flax heat resistance is higher than for cotton, flax bear temperatures well above $200^{\circ} \mathrm{C}$. Flax materials have a long life, but prolonged exposure to sunlight gradually loses its strength [46].

\subsubsection{Use of flax products}

Flax is one of the most used herbs in the textile, food and textile industries. Only, in the form of insulation material, it 


\section{TECCIENCLA}

is commercially available in various forms, either in bulk or as a felt or in sheet form. Linen insulation is mainly used as internal insulation for walls, ceilings and attics. When handling without skin irritation, therefore, insulation easily works without the use of protective equipment, this applies generally to other natural materials, for example. hemp. Linen insulation exhibit very good durability. The disadvantage of flax fibers is their flammability, because they add compounds of ammonium, borax or soluble glass [47]. Another disadvantage is the fragility of the fibers, for this reason, in the linen products, the addition of polyester fiber. The inner bark of the stem is used for textile purposes. Woody stem pain, called. Shiv, originally added to the adobe bricks then presses with a straw binder portfolio for the construction and furniture industry. The seeds are used for the manufacture of linseed oil.

\subsection{Jute}

\subsubsection{Jute cultivation}

Jute (Corchorus) is an annual plant of the Mauve family, the largest taxonomic divisions in the Lipov family. Mentions of jute are already in the Indian epic Mahabharata and in the Old Testament. It was observed that in the 16th century in India the poor were wearing simple clothes made of jute clothes [48]. In 1830 he recorded the first jute yarn manufacturing machine in Dundee, Scotland. Until the late 19th century, they dominated the production and marketing of British jute. In 1855 the first jute articles were opened which weave in India (Kolkata and vicinity), where the jute fiber market was gradually moved [49]. In 2008 about $60 \%$ of the total amount of jute and woven yarns from India came from India. Thermophilic, under moist conditions, plant growth is mainly distributed in the tropical south and Southeast Asia, mainly in India, Bangladesh, China, Thailand, Vietnam, Indonesia, Africa and Australia, with the largest producers of this plant are India, Bangladesh and China. Jute cultivation in Europe and the USA is quite exceptional, at the beginning of the 21 st century only $1.5 \%$ of the total production of jute is processed. [50]

\subsubsection{Characteristics of jute}

Two types of jute are generally known, which are grown worldwide. These are:

a) Corchorus olitorius - known under the Tossa brand, $80 \%$ of the total crop of this commercial crop. The plant grows to a height of 2.5 meters, the leaves have a distinctive elliptical shape, the fruits grow from the elongated capsules. This type of jute, originating from Africa to Asia occurred in the 19th century [51]. b) Corchorus capularis - known as the "white jute." Its action is approximately $10 \%$ of the total harvest. Can grow up to 4 meters, fruits grow from round capsules. The beginnings of its cultivation are registered in the border of India and Burma [51]. Other known species include. Mesta, Bimli and more. For fake jute are considered for example. Alcotan Fiber Theophrastova (Abutilon theophrasti), known as the Jute of China, after Jute of Java, Gambo or Kendu fiber of kenaf (Hibiscus cannabinus, synonyms Hibiscus sabdariffa kenaf hibiscus and kenaf). Jute represent herbs with a fibrous stem, often unbranched, 2-4 meters high, ripen 120 to 150 days after planting. The yield per hectare of this crop is approximately 1.5 to 2 tons. Bright green leaves are simple, lanceolate, petiolate, $5-15 \mathrm{~cm}$ long, with toothed or lobed edge well. Small yellow flowers are sessile or on stems arranged at the top of the inflorescence. The fruit is cylindrical or spherical bowls with many small black seeds.

Made of jute fiber produced rods is the cheapest natural fiber technique for the textile industry, available in sufficient quantities, recyclable and biodegradable [52]. Before the actual transformation of the spinning mill is cut off the bottom of the stem, so-called. "Cut" of 20 to $40 \mathrm{~cm}$, which is sold at a lower price. The stems after harvesting 18-30 days of soaking and then the individual fibers separated from the wood. Followed drying of the fibers after a period of 2 3 days. There are 6-8 kinds of these derivative jute fibers distributed for example according to the strength of fibers and wood or content. Technical fiber resistant to microorganisms and wear, 1500-4000 mm long, elemental sections have a length of 1 to $5 \mathrm{~mm}$, a diameter of around 18 microns. Hygroscopicity of the fibers is about $34 \%$. Its main disadvantage is, however, dust during handling and unpleasant odor. [53]

\subsubsection{Uses of the jute product}

Jute is most commonly used in the textile and food industries. Jute is known as fiber plants, which has a stem fiber bundles recoverable as early as 120 days after germination. After treatment (soaking, rubbing, spinning) obtained from these coarse textile fiber, which is not particularly strong, but is cheap. Fiber is used for making burlap (Saking, burlap), twine, ropes and warp base in carpet fabric (CBS carpet fabric stand). Jute fiber is also rotated along with other yarns for decorative fabrics or fabrics for upholstery. For its crudely jute weaving it is rarely used for clothing. Without staining the fiber is yellowish gray. The smoky flax cultivar is exceptionally bleached or dyed. Jute can also be used for the production of wrapping paper. According to the volume of the world production of plant fibers, jute fibers are only surpassed by cotton fibers. [6] 


\subsection{Other sources}

\subsubsection{Wood}

Generalized and in many ways they rediscovered the origin of wood as raw material. One of the few building materials that can be applied to all parts (support part, insulation materials, interior packaging materials, ...). Instead of wood, other materials are still preferred because of environmental reasons. These include polymeric materials, metallic materials, concrete and the like. Timber producing countries are a trend to use fully grown timber. Develop procedures to fully evaluate the individual parts of trees. The main direction of the application, so far little used raw waste production in the fastening plates and accessories, chemical decomposition, combustion or production of charcoal. The most common wood processing for the production of: pulp, fiber boards, wood flour, wood and charcoal, wood products in the art and toy industry, concrete, smoking articles, lighters, fertilizer, regeneration, energy, bedding for cattle [54].

Good wood insulation products with good mechanical properties are the fiber boards mentioned above, in which a low diffusion resistance, low coefficient of thermal conductivity. These plates can be applied on: additional insulation of buildings such as wood cladding, insulation structures for attics or as insulation (thermal and acoustic) in the floor. [55] If we compare the length of tree growth with the length growth of previous natural alternative resources (hemp, flax, jute and others), the latter materials clearly preferable from the point of view of the environment. It is scientifically proven that 1 hemp seed yields 2.5 to 4 times more pulp with a lower lignin content of 1 hectare of forest.

\subsubsection{Reed}

Reed (Phragmites) grows in Central Europe on the gentle slopes near stagnant waters and slow flowing rivers. This perennial herb of the family Poaceae grows up to a height of 2-4 m, diameter of the stems oscillates between 3-9 mm and. The cane is one of the oldest traditional building materials with average insulation properties. Straw in comparison is much more difficult, is not subject to biological degradation and due to the high content $\mathrm{H} 2 \mathrm{SiO} 3$ is for him a significantly lower risk of spontaneous combustion. During compression of the individual layers of the plant increases the fire resistance. For construction purposes only annual reeds are used, which are transformed into plates, rolls and mats. Its main use in the present construction, the manufacture of plates, as it is then used as a gypsum carrier or insulation plates. The basic task of each coatings ensure its tightness. It was verified that in a thickness of 250 to $350 \mathrm{~mm}$ long can successfully roof to resist atmospheric effects. A significant problem with this cover is to ensure its tightness. [1] In general, cane except Antarctica occurs on all continents, especially in the areas of watercourses and wetlands. In Europe there are large producers of cane from Hungary, Slovakia, Italy. Cane is still used successfully in many countries. Known as the application in the northern regions of Holland and Germany, they are areas that are exposed to abundant precipitation and wind action.

\subsubsection{Straw}

Straw is a good alternative for construction. The cereal area planted in the EU-27 rose in 2011/2012 is 55.5 miles -Ha, which is a slight decrease compared to the period 2009/2010 (58 thousandths Ha.) and 2010/2011 (56.5 thousand Ha.). Percentages on the use of these crops production are used $70 \%$ in agriculture, and the remaining $30 \%$ is surplus. [56]

Found use as garbage, sealing insulation of joints between beams or bullets were placed in a room for thermal protection. Straw was also used in the production of adobe and was added to the plaster. The use of straw in the construction sector is particularly appropriate from the point of view of environmental protection. For the insulation of the straw house it speaks particularly low energy intensity in all phases of the construction process, as well as easy recycling at the end of the life of the structure. Negative impulse for the construction of panels of straw or straw packed in bullets can be particularly high flammability, poor resistance to moisture and pests. However, it is possible to repel water that almost does not accept water and was also resistant to pests.

In construction, straw is used in the form of molded panels or straw bales. For eco panels wheat straw of basic quality pressed material in prismatic bales. Straw form the core of the table. Another essential material is recycled cardboard paper, glue and the natural ingredients of rodents, which are added, in full compliance with hygiene and health levels, accurate metering system. Eco panels today use mostly in place of traditional solid walls of brick, glass and ceramics, plaster, etc. Eco panels needs the support structure is selfsupporting, anchored only on the floor and ceiling. They do not require thermal and acoustic insulation. They are also very interesting alternative to the classic interior trim production hallways, warehouses and other buildings. There is the possibility of using in the non-bearing peripheral walls of the deck with (steel) wooden bearing box. This variant is used in the construction of houses and other buildings [57].

\subsubsection{Sheep wool}

Currently the world lives sheep 1.2 billion, most, but kept the meat and milk. The contribution is more China (171 thousand), Australia (103 thousandth of an inch), The EU (99 thousandth of an inch). And the countries of the former 


\section{TECCIENCIA}

Soviet Union (65 thousand). Each sheep produces an average of 2.5 to $5 \mathrm{~kg}$ of wool, some breeds and $18 \mathrm{~kg}$. The wave is cut once or twice a year, and is stored as an integral web which is then divided in turn depending on the different parts of the quality classes. Sheep wool is the easily renewable source, easily recyclable, raw material environment which is formed by an average of $60 \%$ animal protein fibers, then from $15 \%$ moisture, $10 \%$ fat, $10 \%$ Sheep's sweat and 5\% impurities [58]. Pure fiber is composed of keratin, a pigment and a chemically bonded moisture. The chemical composition of the fiber consists of $50 \%$ carbon, $40 \%$ oxygen and $10 \%$ nitrogen. The fibers have a flaky surface, its special structure gives excellent fiber flexibility. Virtually all sheep wool fiber production is processed in two basic technologies: manufacture of hairstyles and production of carded yarn. [59] Among the advantages of wool range of the following characteristics: clean, easily natural renewable raw materials - easy and comfortable handling, with no possibility of danger to human health (skin, mucous membranes, etc.). Environment-friendly recyclable transparent - selfextinguishing capacity, fibers do not withstand combustion, at high temperature relaxation of material occurs, no change in volume or loss of elasticity and high hygroscopicity.

It is the largest application in the textile industry, but due to its excess is used as the construction of isolation materials, used in particular for thermal insulation of building structures. Its use in the construction of buildings is ample, to meet with her in insulating walls, ceilings, walls and acoustic ceilings. Loss is considered practically without wastage, since any inaccurate cut edge can easily be compressed to the required size [60].

\subsection{Cotton}

Cotton is one of the most important crops for the production of textile fibers. These are mainly plantations in Central Asia and East Africa. In the tropics, they have produced a light cotton cloth for thousands of years. Some sources claim that the Egyptians before 12 thousand. Flights using cotton fabric, were also well-preserved cotton date and 5,000. BC N. L. of Mexico. The first mention of shrubs that produce cotton fibers comes from India from 1500 BC. N. L. In Europe was unknown until the late Middle Ages cotton. During the industrial revolution, however, cotton has become a very important raw material for the textile industry. Today cotton as one of the most important natural fibers, still holds its position, but given the price is often replaced by synthetic fibers.

At present two types of cotton cultivated herbal: cotton and arboreal cotton. These shrubs have yellow flowers that develop in the capsule at the time of maturity. Inside these capsules are hidden small brown seeds with long inner fibers
20-60 $\mathrm{mm}$ hairs white cotton. Given the susceptibility of fibers to infestation of fungi or pests, cotton is cultivated with the support of herbicides, insecticides, pesticides and desiccants, which is not optimal from an environmental perspective. If, however, to improve cotton growing conditions, cotton may represent an interesting alternative raw material for the production of insulation of buildings. Another burden is transport over long distances. [61] In general, however, cotton fibers of good insulating properties, which acts as sheep wool as a good moisture regulator. In construction is used for insulation of buildings, this technology is used more abroad. Manufactured cotton mats, braids, felt rings, sealing wool, but also used as bulk. In thicknesses of 50 to $120 \mathrm{~mm}$ is used for the insulation of walls and inclined ceilings. No partitions are stored as acoustic insulation. Sealing wool and cotton waist are an alternative to mounting foams. Its optimal use is to seal cracks, joints and cavities [57].

\section{Fibers used for the construction of insulation materials and their possible processing}

In the production of insulation materials, a wide range of fibers can be used, whether natural or artificial fibers. The effort of a large number of experts is to develop new ecological materials, whose production does not burden the environment and are economically viable. For this reason, readily available fibers derived from excess production forms or from industrial wastes, but which can be used also in other industries, for example in the manufacture of insulation materials can be used not only in the construction industry. According to the method of fiber formation and its production are recognized basic 2 types:

- Natural fibers; A plant, a farm, a mineral

- Artificial; A natural polymer, a synthetic polymer, a nonpolymer.

To determine the suitability of fibers for the manufacture of insulation materials, the following properties are crucial: fiber thickness, fiber length and high temperature behavior (ignition / temperature melting temperature and burning method). Basic characteristics of natural fibers (length, thickness, ...) are given the conditions of growth fibers, man, these parameters can influence in an indirect way. On the contrary, synthetic fiber, it is possible to make adjustments in its characteristics during the manufacturing process [62].

\subsection{Plant fibers}

Plant fibers are obtained from various parts of the plant. The highest percentage of fiber in the chemical composition is mainly cellulose. 
Table 4 Chemical composition of selected natural fibers.

\begin{tabular}{|c|c|c|c|c|c|c|}
\hline $\begin{array}{l}\text { Fiber } \\
\text { Composition }\end{array}$ & Jute & Flax & Hemp & Kenaf & Sisal & Cotton \\
\hline Cellulose & $\begin{array}{l}61- \\
71\end{array}$ & $\begin{array}{l}71- \\
75\end{array}$ & $\begin{array}{l}70,2- \\
74,4\end{array}$ & $53-57$ & $\begin{array}{l}67- \\
78\end{array}$ & 82,7 \\
\hline Hemicelluloe & $\begin{array}{l}13,6- \\
20,4\end{array}$ & $\begin{array}{l}18,6- \\
20,6\end{array}$ & $\begin{array}{l}17,9- \\
22,4\end{array}$ & $15-19$ & $\begin{array}{l}10- \\
14,2\end{array}$ & 5,7 \\
\hline Lignin & $\begin{array}{l}12- \\
13\end{array}$ & 2,2 & $\begin{array}{l}3,7- \\
5,7\end{array}$ & $\begin{array}{l}5,9- \\
9,3\end{array}$ & $8-11$ & - \\
\hline Pectin & 0,2 & 2,2 & 0,9 & - & 10 & - \\
\hline $\begin{array}{l}\text { Other } \\
\text { Components }\end{array}$ & - & 3,8 & 6,1 & 7,9 & 1 & - \\
\hline Waxes & 0,5 & 1,7 & 0,8 & - & 2,0 & 0,6 \\
\hline Water & 12,6 & 10,0 & 10,8 & - & 11,0 & - \\
\hline
\end{tabular}

According to the origin of the split fibers plant fibers in the following categories: - seed fibers, eg cotton, kapok (singlecelled fibers) - stems or fibrous fibers, e.g. flax, hemp, jute, kenaf (Multicellular technical fibers

Fibers from the leaves, e.g. sisal, Manila hemp, New Zealand flax (multicellular technical fibers), - fruit fibers, for example, coconut fiber (multicellular technical fibers) [63].

Fibrous fibers consist of fiber bundles, each pack contains 10-40 individual cells or filaments attached pectin. One stem contains $20-50$ bundles of fibers. The filaments are composed of several layers. Within the cell is found, for the typical fibers lumen that penetrates the entire length of the fiber. The length of a fiber of this type depends on the height of the plant.

Physical, thermal and technical and mechanical properties of the fibers depend to a large extent on the quality of the fiber, which is affected by many factors, for example: Replacement of atmospheric conditions during plant growth, dew, conditions during fiber processing and storage of fibers, etc. [64]. The most important factor in the processing of natural fibers moisture content, as well as resistance to microorganisms and fire. To define the quality of the fibers of isolation materials, there are basic indicators of quality, such as that set. Purity fibers or microbiological quality. Physical and mechanical properties of natural fibers are mainly dependent on the chemical composition of the fiber (the proportion of cellulose, hemicellulose, lignin, pectin, wax, water content and other associated components), which is connected to the climate during growth of the plant.

Table 4 shows the chemical composition of some natural fibers [65]. The porosity, bulk density, moisture content, material temperature or direction of heat flow are the most important parameters affecting thermal properties. Fibers of the tow are suitable for the creation of thermal insulation materials since they have a porous structure which has a positive effect on density, i.e. To reduce it. The coefficient of thermal conductivity also depends on the distribution, size and shape of pores. These organic materials, the structure is very complicated. Generally, compounds with simple structures conduct heat better than the fibers of the complicated structure. Natural moisture fibers have a significantly negative effect on thermal conductivity. Due to the fact that the fibers of the tow are mainly made of cellulose, the moisture absorption of these fibers affect groups in the hydrophilic fibers of macromolecules and their accessibility to water molecules [66]. The cellulose contains three hydrophilic hydroxyl groups in its structural unit. The water molecules can be attached directly to the active site (groups or groups capable of forming hydrogen bonds with hydrophilic water) or water molecules in the fiber already contained.

The absorption and desorption of moisture results in a change not only heat technique but also the mechanical properties of the fibers. All natural fibers are produced with increased moisture content in the air to increase strength, while at a moisture content of natural fibers of less than $20 \%$ become brittle and brittle, it is for them to dry. Relative humidity greater than $60 \%$ accelerates the possible chemical and biological attack of the material. In general, the polymers in water acts as a plasticizer reducing the glass transition temperature and increasing ductility. Due to the absorption and desorption the size changes fibers - swelling or contraction. Due to the formation of hydrogen bonds in the amorphous zones of the fibers leads to significant lateral inflammation. Longitudinal swelling is reduced. Vast fibers due to the higher content of lignin will swell less. Fibrous materials also have good acoustic properties and can become a full-fledged alternative to conventional materials. As regards the field of sound insulation to airborne noise, the material must have a sound absorption coefficient $\alpha$ favorable. Since the coarse fibers have a porous and fibrous structure, they exhibit favorable coefficients of sound absorption coefficient. Thanks to its excellent mechanical properties and the flexibility of the bast fibers it can have a composite materials used for damping dynamic vibrations in sound impact horizontal structures [67].

Natural fibers at temperatures above $100^{\circ} \mathrm{C}$ are subjected to irreversible changes that significantly affect their properties. On exposure to dry air at $110^{\circ} \mathrm{C}$, the depolymerization fibers (their yellowish color at dimming) at $150^{\circ} \mathrm{C}$, a pyrocelulose and at $240^{\circ} \mathrm{C}$, the fibers are carbonated and carbonate. The consequence is the loss of strength and all other parameters of quality [68] - low resistance to microbiological agents.

If there are optimum conditions for the propagation of fungi and bacteria (high humidity, the presence of oxygen and convenient $\mathrm{pH}$ ), these organisms acquire their enzymatic cleavage nutrients from the substrate. In the metabolism of fungi that produce oxalic acid, lactic acid, tartaric acid, they color the substrate and can be a source of additional damages. In many cases, the presence of mold detects 


\section{TECCIENCIA}

ultraviolet light, which induces in infected places intense yellow fluorescence. All cellulosic fibers are predominantly digested with cellulose, which is capable of hydrolyzing cellulose into frugal sugars. Biodegradation begins fibers in its amorphous region and extends into the crystalline regions. Higher lignin content inside the fiber decreases microbial damage. - Greater sensitivity to humidity [69].

The following section describes selected natural fibers and their basic characteristics, but have already been discussed in section 3 above.

\subsection{Basic characteristics of some natural fibers}

\subsubsection{Hemp fiber}

Thicker, darker and stronger compared to flax fibers are hemp, obtained from the stems of plants. The average fiber length is $20 \mathrm{~mm}$ and thickness is 22 microns. The chemical composition of the fibers is as follows: 70.2 to $74.4 \%$ consists of cellulose, 17.9 to $22.4 \%$ hemicellulose, 3.5 to $5.7 \%$ lignin, $0.9 \%$ pectin, $8 \%$ wax, $10.8 \%$ water and other components $6.1 \%$ [70] [71]. Hemp fabric burns easily and quickly with a bright flame, releasing smells like when burning wood or leaves. The burning of the residue is not perfect melted and burned, ash has a gray color. Hemp fiber has all the natural fibers of high resistance to the elements.

\subsubsection{Flax}

Flax fiber bundles in the plant bark are formed from 15 to 30 elemental fibers, pectin connected to the body length from 20 to $140 \mathrm{~cm}$ and a thickness of 200 to 300 microns [72]. The individual filaments typically have a length of $17-$ $40 \mathrm{~mm}$ and a thickness of $12-17$ microns. The main component fibers composed of $75 \%$ cellulose, $20 \%$ are in the representation of hemicellulose and the rest are pectins and other ingredients. Compared to hemp fibers contain less lignin, approximately $2.2 \%$. To obtain from the fibers of the flax plant, it is necessary to harvest these crops by soaking or spraying. These processes separate linen (9\%), used in the textile industry, and tow (7\%), even more usable in other sectors. Waste product is shingles, useful for the production of board building materials. Flax fiber fabric is highly flammable. If the long-acting flame is ignited. However, it can easily be extinguished by blowing [73] [74].

\subsubsection{Jute fibers}

Jute fibers are second most widely used textile fiber in the world, after cotton. The fibers are obtained from the tow of which must be peeled manually. Further treatment is similar to flax. Fibers excellent resistance to microorganisms. The effect of light, heat and moisture released filaments, which means that jute products considerably dust. Technical fiber is 1.5-4 meters long and strongly lignified, due to the high proportion of lignin, elemental sections have a length of 1 to $5 \mathrm{~mm}$ and a thickness of 15 microns. The flame behaves like jute, flax or hemp [75] [76].

\subsubsection{Cotton fibers}

The cotton fibers are 20-60 mm, white cotton fiber covering the forehead long. Its quality reflects the length of the fibers (or staples) and the uniformity of staples. The highest quality cotton fibers $(50-60 \mathrm{~mm})$ of staples are quite rare and are used by luxury items [76]. Typically, cotton fibers of generalized quality have a fiber length of $28-40 \mathrm{~mm}$ are used alone or mixed with artificial fibers for the production of light knitwear outerwear, underwear and bedding, and many other Applications. Most often used in practice with a fiber length of $28 \mathrm{~mm}$, where the fibers are suitable for use in fabric manufacturing, less demanding on the uniformity and softness of the yarn, such as denim, sheets, towels Rough, and the like. Poor quality cotton (staple 11 to $18 \mathrm{~mm}$ ) is used for example. In the production of work clothes.

Cotton fiber is almost exclusively made up of cellulose up to $96 \%$. It represents the purest natural source of cellulose. The thickness of the fibers is in the range of 12-17 microns. Natural cotton is fire retardant, in which combustion occurs at temperatures around $400{ }^{\circ} \mathrm{C}$. Cotton is flammable when exposed to a flame, and can catch fire. During combustion it emits a fetid odor like paper (which is caused by high levels of cellulose) in flames. The smoke is gray or white. Ash is a fine, easily disintegrates, without sintered balls [73] [75] [76].

\subsection{Animal fibers}

Fibers of animal origin, unlike natural fibers based on proteins [77]. They are most often obtained from animal skins or from insect secretions, which is divided into two basic groups: - keratin fibers (hair) - sheep wool and other hairs, for example mohair, cashmere, angora, Called skin, camel hair and hair. Goat, dog, cow, horse hair, human hair, etc., - fibroin fibers (insect droppings) - real natural silk, wild silk, spider silk [80]. From the point of view of its use for the development of insulating materials of keratin fibers are more suitable

\subsubsection{Wool fibers}

Generally wool obtains from animal hair. Wool fibers are made up of keratin as well as hair. The sheep wool most used and available in our latitudes. Wool is obtained in the form of a live shearing net. The increase of sheep wool to diminish the state of any natural resource. The cuts are usually once a year; some breeds can be cut twice a year. The fleece is formed by a continuous layer of hair, hair grease coupled and sweat. The finer fibers can be found on the shoulder 


\section{TECCIENCLA}

blades and hips, while the worst quality fiber can be found in the sheep's head. Batting comprises a large number of impurities which must be removed by repeated washing in water at $40^{\circ} \mathrm{C}$ with the addition of $0.5 \mathrm{~g}$ of detergent powder and $1 \mathrm{~g}$ per 1 liter of soda water. Washing with separate dirt and lanolin. The lanolin is composed of sheep fat contains wax quota. It consists of $65 \%$ wax, $15 \%$ paraffin oil and $20 \%$ water. The thickness of the wool fibers depends on the ovine species, most frequently in the range of 25-45 microns [81]. The length of the fiber is determined by the length of the ovine species and hair, the order in the range of 20 to $80 \mathrm{~mm}$ [81]. The wool is non-flammable. It has an ignition temperature of $560{ }^{\circ} \mathrm{C}$, and flame retardant capacity. At higher temperatures sizzle, giving a strong smell to burnt hair or feathers and produces black smoke and light smoke. The ash contains large pieces of dark, fragile, unburnt fibers. Sheep wool is processed by combing or carding. Most wool yarns, however, are mixed with artificial fibers, less frequently, with a movement of other animals. They are used in particular for lightweight fabric or knitted outerwear. Carded yarn is used to make thick outerwear and as a thread of rugs and duvets and pillows filled. Recently, when there is an increasing expansion of synthetic fibers, there is a surplus of wool world. One way to process these surpluses is the use of raw fibers in the construction industry for the production of thermally and acoustically insulating mats.

\subsection{Chemical fibers}

Chemical fibers are defined as textile fibers obtained by chemical means. The basic division of chemical fiber is as follows: - synthetic fibers of natural polymers; Of cellulose fibers from regenerated cellulose (viscose fibers, cuproamonium, nitrate), cellulosic fibers of cellulose derivatives (fiber acetate, diacetate), acid fibers (alginate fibers), protein from regenerated animal proteins (casein, keratin, fibroin fibers) from regenerated vegetable protein fibers (soybean fibers, zein) - Chemical fibers of synthetic polymers; Polyamides, polyesters, a polyethylene, a polypropylene, a polyacrylonitrile, a polyurethane and the like, inorganic chemical fibers (metal fibers, based on silicon, carbon, other low molecular weight substances, single crystal). From the above summary, it is evident that insulating materials are particularly useful in polymeric fibers, whether derived from natural or synthetic polymers. [82].

\subsubsection{Chemical fibers of natural polyesters}

These fibers are formed artificially, respectively, formed by the modification of natural polymers. The most common natural polymer exploited for the production of chemical fibers is cellulose. Natural polymer fibers Therefore chemical subdivide into regenerated cellulose fibers, and fibers composed of cellulose derivatives. By regenerated cellulose fibers it is pure cellulose, and therefore its properties are similar to natural cellulose fibers. This category includes viscose, cupro-ammoniacal and lyocell fibers [82].

\subsubsection{Viscous fibers}

The most widespread chemical fibers from natural polymers is the world's annual production of around 3.8 million tons viscose fibers which make up $80 \%$ of production in this group. As feedstock used chips from pine or beech wood. Chips is soaked for several hours in a bath of $17 \% \mathrm{NaOH}$ solution whereby a cellulose arises the alkali after ripening occurs xanthation, i.e. C2S exposure to alkali. The resulting product is a cellulose xanthate, yellowish loose mass from which followed by dissolving in dilute $\mathrm{NaOH}$ arises brown solution called viscose. Then the solution is filtered and deaerated, to allow it to spinning. The viscose is spun in a solution of $\mathrm{H} 2 \mathrm{SO} 4$ and $\mathrm{Na} 2 \mathrm{SO} 4 \mathrm{ZnSO} 4$ while reverse excretion $\mathrm{C} 2 \mathrm{~S}$. The fibrous material passes through a nozzle, whose size determines the diameter of the finished fiber. At the same time spinning, still in the plastic state, the fiber is stretched, thereby increasing its strength and orientation, eventually also chemically modifies or cut to staple length. The viscose fibers are chosen according to the size of the nozzle diameter from 10-50 microns, under the microscope appears as a grooved rod. They are well-flammable, beginning destruction occurs even at $174-190{ }^{\circ} \mathrm{C}$. It burns without a flame does not melt, while emits a foul odor similar to burning paper. It leaves a fine, gray ash. Among the advantages of the use of viscose fibers include in particular the very favorable price (less expensive than cotton $2 \mathrm{x}$ and $4 \mathrm{x}$ cheaper than sheep wool), but the production process is environmentally unsustainable. 1 ton of viscose fibers consumes approximately $6 \mathrm{~m} 3$ of timber and two tons of chemicals [82].

\subsubsection{Copper-ammonium fibers}

It is a fiber of circular cross-section under a microscope to look sticks. For the production of these fibers are used in a process for dissolving cellulose CUOXAMU, i.e. in tetracopper-ammonium hydroxide [83]. For production it is necessary very pure cellulose (at least 96\%). The raw materials used linters, therefore non-processed fibers covering the cotton seeds after seeding operations, or boiled and bleached, pure cotton residues from the production of cotton goods. Spinning is carried out in two ways: a) Twostage coagulation - the first step is precipitation in the flowing water. Emerging gel concentrates and significantly extends (up to 80x). The second stage is an acidic bath $\mathrm{H} 2 \mathrm{SO} 4$ at which precipitation occurs cellulose. Formed soft, good fiber, but little solid fibers. b) Alkaline spinning principle is spinning and coagulation in a bath of $\mathrm{NaOH}$. This creates a thicker and stronger fibers. 


\section{TECCIENCIA}

The fire, however unstable fibers. Already at $150^{\circ} \mathrm{C}$ loses strength at 170 to $205^{\circ} \mathrm{C}$ occurs decomposition. Previously widely used for women's gossamer stockings and underwear today from it only produces clothing accessories, and its use is rather marginal.

In contrast, fibers of cellulose derivatives have different properties compared with natural cellulose fibers, the differences include e.g. be thermoplastic, smaller hygroscopicity. This group includes the different kinds of acetate fiber. Meet can also proteinaceous fibers, which is differentiated from fibers recovered from the animal protein (casein, keratin, fibroin), but also regenerated from plant proteins (soy, zein) [82].

\subsubsection{Lyocell fibers}

A huge environmental burden in the production of viscose and high toxicity led to a search for other, more environmentally-friendly production processes to obtain the same quality of regenerated cellulose fibers. The result was lyocell fibers. In their manufacture is used a solvent system based on $\mathrm{N}$-methylmorpholine $\mathrm{N}$-oxide (NMMO). Thanks to the strong dipole of $\mathrm{N}-\mathrm{O}$ can be physically dissolving cellulose in an aqueous solution. The advantage is that the NMMO solvent is recycled and almost $100 \%$ reused. Environmental burden is therefore significantly lower than that of viscose.

In practice, the lyocell fibers used alone, but more often mixed with flax, cotton, wool or polyester in the textile industry. [82]

\subsubsection{Acetate fibers}

These are fibers from cellulose derivatives, in particular from esters. These fibers are made of very pure cellulose $(97-99 \%)$, acetylation, where the cellulose is swollen in a solution consisting of glacial acetic acid, $\mathrm{CH} 3 \mathrm{COOH}$, $\mathrm{H} 2 \mathrm{SO} 4$, sulfuric acid and acetic anhydride $\mathrm{CH} 3-\mathrm{CO}-\mathrm{O}-\mathrm{OC}-$ $\mathrm{CH} 3$. Before spinning, it is necessary to produce a spinning solution having a concentration of $20-35 \%$, composed of $85 \%$ acetone and $15 \%$ ethanol. Spinning is performed by two methods. The former method is a wet spinning into water, at present, however, utilizes dry spinning method is run at a temperature of 60-80 ${ }^{\circ} \mathrm{C}$, which involves simultaneously drying the fibers and solvent evaporation. Stabilization of the fibers is carried out in steam or in air. Triacetate fibers are produced similarly, only omits the process of saponification. These fibers can, however, also be obtained by spinning from the melt. High gloss acetate fibers are lighter than the fibers of natural silk. Their strength is about half lower, but are much cheaper. Acetate fibers belong to the group of thermoplastic fibers. They are easy to ignite, but burn slowly. Under the microscope they are heavily grooved surface. In the vicinity of the flame melts the end to form a hard black balls. When burning emit typical pungent smell similar to vinegar [82].

\subsubsection{Chemical fibers with synthetic polymers}

Synthetic fibers today are the largest group of technical fibers and their importance is increasing. Often they are a substitute for other fibers due to lower cost price and especially some special characteristics, e.g. A very high mechanical strength, flexibility, durability, other fibers which do not. However, they have also some drawbacks, especially the very poor behavior at high temperatures (heat materials to soften and melt, often during combustion releases toxic fumes). UV rays are often synthetic fibers degrade and ultimately also pose environmental burden at production and recycling. For synthetic fibers, can be specifically varied chemical composition, geometry and structure. The basic unit is always the monomer is further polymerized (polycondensation, polyaddition, chain polymerization), i.e. formed long chains of polymers. At present the most extended fibers are polyamide, polyester and acrylic [84] [85].

\subsubsection{Polyamide fibers}

The second is among the most used synthetic fibers. In the sense of the chemical nature of the polyamide fibers, they are formed in two basic polycondensation, most commonly used forms, polyamide 6 and polyamide 6.6 , which differ in molecular structure and some properties. Polyamide 6 (PA $6)$ is known under the trade names Perlon (Germany), caproate (Russia) or Nylon 6 (USA). The main raw material source for the production of phenol, which in turn regulates the caprolactam. Caprolactam mixture with water, is heated in an inert atmosphere and at $270^{\circ} \mathrm{C}$ in an anaerobic environment melted. The melt is formed in the extrusion nozzle and is drawn off the cooling shaft, subsequently stretched under hot or cold. Polyamide 6.6 (PA 6.6) sold under the tradename Nylon (USA) or Anid (Russia), is produced by mixing methanolic solutions of adipic acid and hexamethylenediamine at the boil. A white nylon salt. The polycondensation takes place in a solution of $60 \%$ nylon salt in water by heating in an autoclave at $260-280{ }^{\circ} \mathrm{C}$ for $4-16$ hours. At $270{ }^{\circ} \mathrm{C}$ the melt and then again to pass through the press-through nozzles. Compared PAD 6 crystallizes much faster, therefore it must be in a cooling shaft blow-off steam. The last step is again drawn. From a technical perspective it is preferable fiber PAD 6.6 It features a higher strength, lower water absorption and a higher melting temperature $\left(256^{\circ} \mathrm{C}\right.$ versus $\left.220^{\circ} \mathrm{C}\right)$. Common characteristics are high resistance to abrasion and tearing, easy moldability, however, they also tend to photodegradation (already mentioned UV radiation) and substantial sensitivity to 


\section{TECCIENCLA}

higher temperatures (even at 90 to $100{ }^{\circ} \mathrm{C}$ decreases the strength). The flame burns easily and quickly, while they tend to melt. They are self-extinguishing, but the resulting melt, as well as escaping smoke is very dangerous. When there is no burning ash, only hard black balls. Released odor reminiscent of celery [85].

\subsubsection{Polyester fibers}

Polyester fibers occupy the market with synthetic fibers first place, the production of around $47.5 \%$, their popularity continues to rise. Main feedstock to obtain polyester fiber oil. The production process of the fibers is similar to that of polyamide fibers, thus catalyzed polycondensation at a temperature between $220-270^{\circ} \mathrm{C}$.

The fibers collect melt spun through the nozzle and subsequent stretching and fixation. Polyester fibers have very good mechanical properties and abrasion resistance, can withstand higher temperatures (softening point $230^{\circ} \mathrm{C}$, melting point $258^{\circ} \mathrm{C}$ ) are stable to light and to weathering and can be very easily modified chemical additives that affect their end Properties. The fire quickly burns leads to shrinkage and form a hard black balls. In combustion emits slightly sweetish, chemical smell, leave no ash, but his black smoke and fumes are very dangerous. Polyester fibers are very durable, have wide industrial use [86].

\subsubsection{Acrylic fibers}

Acrylic fibers occupy the third spot in the production of synthetic fibers, the basic component of the acrylonitrile units (PAN). The feedstock for the production of acrylic fibers is poisonous liquid acrylonitrile $\mathrm{CH} 2=\mathrm{CH}-\mathrm{CN}$, which is further processed by polymerization. To spin not melt because it decomposes. Spinning may be done in several ways, either runs dry from a solution in dimethylformamide (DMF) at $80-150{ }^{\circ} \mathrm{C}$ or a wet coagulation bath of water and dimethylformamide or a combination of these methods (a method by dry-jet-wet). Acrylic fibers have over other synthetic fibers less resistant to abrasion and have a tendency to pilling, but excel in good thermal insulation properties, sufficient UV resistance and lower price. At $235^{\circ} \mathrm{C}$ begin to soften gradually precipitation. They are highly flammable, in the heat tend to drip. Melt them like smoke and fumes, highly dangerous. When burning emit a strong, pungent odor similar to the smell of the fish [86].

\subsubsection{Polypropylene fibers}

Production of polypropylene fibers industrially began in 1960 in Italy. The production of the fibers takes place by polymerizing propylene using Ziegler-Natta catalysts (titanium halides). Polypropylene fibers obtained from a melt, then subjected to cooling in a long shaft and stretching.
Fibers are specific to their high coefficient of friction, high strength and ductility, lightness, durability and ease of formability. The softening temperature is in the range from 149 to $154^{\circ} \mathrm{C}$, the melting point in the range $165-170{ }^{\circ} \mathrm{C}$. Compared to other synthetic fibers are specific low coefficient of thermal conductivity of 0.1 to 0.3 W.m-1.K 1. Among the disadvantages are particularly low UV resistance [86].

\subsubsection{Bicomponent fibers}

These fibers are also referred to as multi-component fibers or fiber for short BiCo. Produced by spinning two different polymers most often using a special spinneret [86]

The fibers of core-sheath and side by side are used in the manufacture of nonwoven articles as a binder. Usually consist of higher and lower melting polymer component. Most often the function of higher-melting polyester component and a lower melting copolyester component or polypropylene. Bicomponent fibers are applied in a mixture with the basic fiber or alone. During the bonding of the fiber due to higher-melting component not collapse and that they have higher bulkiness. Adhesive joints are formed at intersection points of the fibers. We call them spot. The greater part of the fibers consists of then relatively moving portions between the joints. This leads to products with good flexibility and low initial modulus in tension. The small size of the bonding sites but increasing demands on the participating mutual adhesion of polymers, which is generally a problem. Fibers type islands in the sea are used for the formation of very fine fibrous structures extraction matrix. Fibers having a cross-section is produced for its ability to split to several fine fibrils. Their use is difficult to circumvent the problems of workability and very fine fibers after splitting achieves the feel of fine products [86].

\section{Conclusions}

In the present text a complete summary about the possibilities for acoustic insulation within the principles of sustainable development has been reported. Inside each one, milestones on development have been analyzed and contextualized inside historical frame.

The research is divided into natural, inorganic, organic and synthetic materials, and in each one of them, the methods for processing and the insulation characterization are described. The main goal of the paper is to address that some variants of possible insulation materials are friendly with the ecosystem and that a proper resource exploitation should be always the starting point in the construction and building industry. 


\section{TECCIENCIA}

\section{References}

[1] F. Asdrubali. Survey on the Acoustical Properties of New Sustainable Materials for Noise Control. In: EURONOISE 2006, Finland.

[2] D. A. Páez, M. Herrera Martínez and L. A. Calderón Bermúdez Possibilities for the Development of Acoustic-Mechanical Systems based on Colombian Typical Fibres. In. Proceedings of ICSV23, Athens, Greece. 10-14 July, 2016.

[3] M. Herrera Martínez, A. Gualtero Mosquera, R. E. Rincón Flórez "System and Software Development to Measure Cylindrical Pipes based on Acoustic Reflectometry". In: Tecciencia. 2013. DOI http:/dx.doi.org/10.18180/tecciencia.2013.15.9.

[4] H. Benkreira, A. Khan, K. V. Horoshenkov. Sustainable acoustic and thermal insulation materials from elastomeric waste residues. In: Chemical Engineering Science. Volume 66, Issue 18, 15 september 2011, pages 4157 4171. ELSEVIER.

[5] F. Asdrubali, S. Schiavoni, K. V. Horoshenkov. A Review of Sustainable Materials for Acoustic Applications. In: Builiding Acoustics, Vol 19, Number 4, 2012. Pages 283-312.

[6] Bjorn Berge. The ecology of building materials. Bjorn Berge. Second edition. ELSEVIER, Architectural Press, 2009.

[7] Mangesh V. et al. (2013) Application of agro-waste for sustainable construction materials: A review; Construction and Building Materials 38 , 872-878.

[8] Kates, R. W., Parris, T. M., Leiserowitz, A. What is sustainable development?, In: Environment. ProQuest. Apr 2005: 8-21.

[9] J. Meadowcroft. Who is in charge here? Governance for Sustainable Development in a Complex World“. Journal of Environmental Policy and Planning. Vol. 9, No. 3-4, Sep/Dec 2007, 299-314.

[10] Are we planning for Sustainable Development? An Evaluation of 30 Comprehensive Plans. In: Journal of the American Planning Association. Vol 66, 2000, Issue 1.

[11] P. Naess. Urban planning and Sustainable Development. In: European Planning Studies. Vol 9, 2001, Issue 4

[12] K. Walczak, J. Olszewski, M. Zmyslony. Radon permeability of insulating building materials. In: NUKLEONIKA 2016; 61(3): 289-293. Ed. De Gruyter.

[13] Publications of the National Bureadu of Standards. July 1960-June 1966. United States Department of Commerce. Issued April 3, 1967.

[14] ICNIRP Guidelines: Guidelines for limiting exposure to time-varying electric, magnetic and electromagnetic fields (up to $300 \mathrm{GHz}$ ). Health Physics 74 (1998) 494-522.

[15] Polk, C., 1986. In: C. Polk and E. Postow: Handbook of biologica effects of electromagnetic fields. CRC Press, Boca Raton, Florida. 503pp.

[16] Environmental assessment of enzyme use in industrial production -a literature review- In: Journal of Cleaner Production“. Vol 42, 2013, pp 228 240. ELSEVIER

[17] C. Turley, J-P. Gatusso. "Future biological and ecosystem impacts of ocean acidification and their socioeconomic-policy implications". In Current Opinion in environmental sustainability. Vol. 4, Issue 3, 2012, pp:
278-286.

[18] "Synthetic Strategies in the Preparation of Polymer/Inorganic Hybrid Nanoparticles". In: Materials, 2014, 7, 4057-4087. ISSN 1996-1944.

[19] Van Krevelen, D. W.: Properties of Polymers (3rd ed.), Elsevier, Amsterdam, 1997

[20] Alger, M. S.: Polymer Science Dictionary, Elsevier Applied Science, London, 1989, 439.

[21] Nichols P.H. (1991) in Jones K.C. (ed) Organic Contaminants in the Environment: Environmental Pathways and Effects. Elsevier Applied Science, London. 87-132. Cited in Johnston \& McCrea (1992) Death in Small Doses (Greenpeace International)

[22] ISO 15392 ISO 15392 (2008): Sustainability in building construction - General principles.

[23] Kirchner Doris (DIBt): Health evaluated construction products: experiences in Germany and a new challenge for Europe, Product Policy and IAQ 23/09/2010.

[24] EIO Thematic Report, 2011. Resource-efficient construction. The role of eco-innovation for the construction sector in Europe.

[25] Steve Charter, (2000) Planning for Sustainable Construction \& Development: A guide to Positive Planning for 21st Century Buildings \& Development, Somerset Trust for Sustainable Development.

[26] F. Stevenson \& N. Williams (2000) Sustainable Housing Design Guide for Scotland, Scottish Homes \& Scottish National Heritage, HMSO

[27] James Wines (2000) Green Architecture, TaschenKoln/ London.

[28] Margit Pfundstein, Roland Gellert, Martin Spitzner, Alexander Rudolphi. Insulating Materials: Principles, Materials, Applications. Ed. Detail Practice.2007.

[29] Burns, L. D., Mullet, K. K., \& Bryant, N. O. (2011). The business of fashion: Designing, manufacturing, and marketing (4th ed.). New York: Fairchild Books.

[30] CHINA: New discoveries of ancient treasures. The UNESCO Courier: A window open on the world. December, 1972.

[31] Mignoni, G. (1997), 'Cannabis as a licit crop: recent development in Europe', Bulletin on Narcotics XLIX and L, No. 1 and 2.

[32] Arnaud L., Gourlay E., 2012, Experimental study of parameters influencing mechanical properties of hemp concretes, Construction and Building Materials, 28, 50-56.

[33] Bruijn P.B., Jeppson, K.H., Sandin, K., Nilson C., 2009. Mechanical properties of lime-hemp concrete containg shives and fibres, Biosystems Engineering, 103, 474-479.

[34] Cigasova J., Stevulova N., Junak J., 2013, Properties monitoring of fibrous composites based on hemp hurds with different mean particle size, Polllack Periodica, 8.

[35] Colinart T., Glouannec P., Chauvelo P., 2012, Influence of the setting process and the formulation on the drying of hemp concrete, Construction and Building Materials, 30, 372-380.

[36] Tran Lea A. D., Maaloufa C., Maia T. H., Wurtzb E., Collet F., 2010, Transient hygrothermal behaviour of a hemp concrete building envelope, Energy and Buildings, 42, 1797-1806. 


\section{TECCIENCIA}

[37] Tröedec M., Peyratout C., Smith A., 2009, Influence of various chemical treatments on the interactions between hemp fibres and a lime matrix, Journal of the European Ceramic Society, 29, 1861- 1868.

[38] Suzanne Montfort and Ernest Small. A comparison of the biodiversity friendliness of crops with special reference to hemp (Cannabis sativa L.) Journal of the International Hemp Association. Vol. 6, No.2, 53-63.

[39] Paolo Ranalli, (Ed.). Advances in Hemp Research. Food Products Press, New York/London, 1999.

[40] Groot, B. Hemp pulp and paper production: Paper from hemp woody core. Wageningen, The Netherlands [online]. 2. 3. 1995, [cit. 2010-03-19] <http://www.hempfood.com/IHA/iha02112.html>.

[41] Algirdas Vaclovas Valiulis. A History of Materials and Technologies Development. Vilnius Technika, 2014. 444pp.

[42] Allaby, R.G., G.W. Peterson, D.A. Merriwether and Y.B. Fu, 2005 Evidence of the domestication history of flax (Linum usitatissimum L.) from genetic diversity of the sad2 locus. Theor. Appl. Genet., 112(1): 5865 .

[43] Foulk, J.A., D.E. Akin and R.B. Dodd, 2002. Flax fiber: Potential for a new crop in the southeast. In: Janick,J. and A. Whipkey (eds.), Trends in New Crops and New Uses. ASHS Press, Alexandria, VA, USA, pp: $361-$ 370.

[44] McHughen, A., 1995. Just the flax. Bio-Technology, 13(9): 926-926.

[45] Structure of Plants and Fungi. Edited by: Zoltán Kristóf by Pál Vági, Éva Preininger, Gábor M. Kovács, Zoltán Kristóf, Károly Bóka, and Béla Böddi Copyright @ 2013 Eötvös Loránd University.

[46] Flax fibre and its composites - A review. In: Composites, Part B. ELSEVIER, 2013.

[47] Hall, A. J. A Handbook of Textile Finishing, The National Trade Press Ltd, London, 1957.

[48] THE STORY OF LINEN. W. F. Leggett. 1945, Chemical Publishing.

[49] D. Chapman, "The Establishment of the Jute Industry: A Problem of Location Theory?" In: Review of Economic Studies, 6 (19380, pp.33-55.

[50] Menzies, I. and Chapman, D. The Jute Industry in H. Silverman, (ed) Studies in Industrial Organization (1946), p.237.

[51] Ahmed G, Hossain ABM, Mamun ANK, Roy PK, Hossain M. 1999. Approaches to develop genetic transformation system in jute, Corchorus capsularis L. Yar. D-154. Proc. of the workshop on Application of Biotechnology in the improvement of jute, kenaf and allied fibres phase 2 pp. $28-38$

[52] INDUSTRIAL APPLICATIONS OF NATURAL FIBERS. Structure, properties and technical applications. Jorg Mussig. WILEY, 2010.

[53] SURVEY OF INDUSTRIAL CHEMISTRY. P. J. Chenier. $3^{\text {rd }}$ Edition, Kluwer Academic/Plenum Publishers, 2002.

[54] Abbot, P., Lowore, J., Khofi, C., Werren, M., 1997. Defining firewood quality: A comparison of quantitative and rapid appraisal techniques to evaluate firewood species from a southern African savanna. Biomass and Bioenergy 12, $429 \pm 437$.

[55] The Case for Tall Wood Buildings - How Mass Timber Offers a Safe, Economical, and Environmentally Friendly Alternative for Tall Building Structures, Green, Michael, available online cwc.ca. 2012.
[56] Ma J, Li X L, Xu H, Han Y, Cai Z C and Yagi K Effects of nitrogen fertilizer and wheat straw application on $\mathrm{CH} 4$ and $\mathrm{N} 2 \mathrm{O}$ emissions from a paddy rice field. Aus J Soil Res 45 (2007) 359-367.

[57] Dictionary of Architecture and Construction. $4^{\text {th }}$ edition, Cyril M. Harris. McGraw Hill.

[58] Advances in Wool Technology. N.A.G. Johnson and I.M. Rusell. Woodhead Publishing in Textiles: Number 72, England, 2009.

[59] Walton, P. Textiles, cordage and raw fibre from 16-22 coppergate. the archaelogy of york. volume 17: the small finds. 1989. ISBN 0906780799.

[60] Almusaed, A. and Almssad, A. Insulation materials in context of sustainability. InTech Publisher, 2016.

[61] Wretfors, C. and Svennerstedt, B. Bio fibre technology used for military applications - an overview. Rapport 12, 2006.

[62] Non-destructive testing: A guidebook for Industrial Management and Quality control personnel. IAEA-TCS, Vienna, 1999.

[63] Baiardo M., Zini E., \& Scandola, M. (2004). Flax fibre-polyester composites. Composites: Part A, Vol. 35, pp. (703-710).

[64] P.M. Tahir, A. B. Ahmed, S. O. A. Saiful Azry, Z. Ahmed. Retting process of some bast plant fibres and its effect on fibre quality: a review. In: Bioresources. 2011 6(4). 5260-5281

[65] "Chemical Composition of Natural Fibers and its Influence on their Mechanical Properties". In: Mechanics of Composite Materials. July 2014, Vol. 50, Issue 3, pp 359-376

[66] "Vegetable fibers in polymeric composites: a review". In: Polímeros. Vol. 25, No. 1. Brasil, 2015. http://dx.doi.org/10.1590/0104-1428.1722.

[67] "Structural composite materials tailored for damping". D.D.L. Chung. In: Journal of Alloys and Compounds. 2003. ELSEVIER.

[68] K.L. Pickering, M. G. Aruan Efendy. A review of recent developments in natural fibre composites and their mechanical performance"., T.M. Le. ELSEVIER, 2016, pp 98-112.

[69] Solid Waste Management. Vol 1. UNEP IETC and CalRecovery, Inc.

[70] Zhan HY. Fiber chemistry and physics. Beijing: Science Press; 2005.

[71] Gao J, Tang LG. Cellulose science. Beijing: Science Press; 1996

[72] Z. Saleem, H. Rennebaum, F. Pudel, E. Grimm. Treating bast fibres with pectinase improves mechanical characteristics of reinforced thermoplastic composites. ELSEVIER. In: Composites Science and Technology (2007).

[73] P. G. Tortora and B. J. Collier, Understanding Textiles, Prentice-Hall, New Jersey, NJ, USA, 5th edition, 1997.

[74] R. Pfefferkorn, Oregon Fiber Flax for an American Linen Industry, O. S. C. Cooperative Association, Corvallis, Ore, USA, 1944.

[75] Levetin-McMahon: Plants and Society. 5th edition. McGraw-Hill Companies, 2008.

[76] Howard L. Needles. Textile Fibers, dyes, finishes and processes: A Concise Guide. Noyes Publications, 1986

[77] T. Scheibel. Protein fibers as performance proteins: new technologies and applications“. ELSEVIER, In: Current Opinion in Biotechnology. 2005. Pp:427-433 


\section{TECCIENCIA}

[78] A.S. Tatham, P.R. Shewry. Comparative structures and properties of elastic proteins. Philos Trans R Soc Lond B Biol Sci, 357 (2002), pp. 229234

[79] „An inventory of fibres to classify their potential hazard and risk“. Health and Safety Laboratory (2006). Research Report.

[80] Materials Science and Technology teachers handbook. Science Education Programs. Pacific Northwest National Laboratory. 1994.

[81] S. R. Karmakar. Chemical Technology in the pre-treatment processes of textiles. ELSEVIER, Textile Science and Technology. 1999.

[82] S.V. Purane, N. R. Panigrahi. Microfibres, Microfilaments and their applications. In: AUTEX Research Journal, Vol. 7, No. 3, September 2007.

[83] S .K. Pal. Microfibre - Production, Properties \& Application. Textile ASIA, Vol. 24, Jan 1993, 53-58.

[84] Handbook of Technical Textiles. R. Horrocks, S. C. Anand. CRC Press, Woodhead Publishing Limited, England, 2000.

[85] Master's Thesis. „Feasibility study on fiber reinforced polymer cylindrical truss bridges for heavy traffic". Mathis Chlosta, 2012. TU Delft.

[86] „Fiber development by multicomponent melt-spinning“. R. Hufenus. In: 11th World Textile Conference AUTEX. 2011. 